Check for updates

Cite this: RSC Adv., 2017, 7, 38100

\title{
New and bioactive natural products from an endophyte of Panax notoginseng $\dagger$
}

\author{
Jun Xie,,$^{a}$ Ying-Ying Wu, ${ }^{a}$ Tian-Yuan Zhang, ${ }^{a}$ Meng-Yue Zhang, ${ }^{a}$ Wei-Wei Zhu, ${ }^{a}$ \\ Elizabeth A. Gullen, ${ }^{b}$ Zhao-Jie Wang, ${ }^{c}$ Yung-Chi Cheng ${ }^{b}$ and Yi-Xuan Zhang (DD *a
}

Five new derivatives of macrolide antibiotic Brefeldin A (BFA, 6), named as Brefeldin E1-E5 (1-5), along with Brefeldin A 7-O-acetate (7), mycotoxins (8-9) and mangrovamides A (10) were produced by an endophytic fungus, Penicillium sp., which was isolated from the healthy root of Panax notoginseng. The structures of 15 were established on the basis of their spectroscopic data, while the absolute configurations were assigned using a modified Mosher's method. All compounds were evaluated for their cytotoxic, antiviral and antimicrobial activities. Compounds $1-5$ and 8-10 displayed low or moderate cytotoxicity against a panel of cancer cell lines. Compounds 1, 2, 4, 5, and 8-10 showed moderate antimicrobial activity. Compound 6 showed strong anticancer and antiviral properties. Additionally, it demonstrated broadspectrum activity against human pathogenic bacteria and fungal pathogens that can cause root-rot disease in Panax notoginseng, including Escherichia coli, Staphylococcus aureus, Bacillus cereus, Klebsiella pneumonia, Candida albicans, Fusarium solani, Cylindrocarpon didynum and Alternaria panax. Compound 7, which could be mediated by 6 through the acetylation at the 7-hydroxyl, showed similar bioactivities to compound 6 . Further studies of the cellular mechanism of compounds 6 and 7 showed that they arrested HepG2 cells at the S phase. Due to the similarities in the basic carbon skeleton and the chemical construction correlations between compounds 1-7, the plausible biosynthetic pathway of the BFA series of compounds has been proposed and their structure-activity relationships are also discussed.

Received 26th June 2017 Accepted 24th July 2017 DOI: $10.1039 / \mathrm{c} 7 \mathrm{ra07060h}$ rsc.li/rsc-advances

\section{Introduction}

Panax notoginseng F. H. Chen (Araliaceae) is a valued traditional Chinese medicinal herb. ${ }^{1}$ In traditional herbal prescriptions, it has been widely used for thousands of years as a highly important medicinal plant for its antioxidant, ${ }^{2}$ antidiabetic $^{3}$ and antitumor ${ }^{4}$ pharmacological effects. As a perennial plant, $P$. notoginseng should be grown in the field for at least three years to obtain high-quality raw roots. ${ }^{5}$ Because of the required longterm continuous cultivation, ${ }^{6-8} P$. notoginseng is vulnerable to attacks by soil-borne pathogens including fungi, bacteria, and nematodes. Endophytic fungi play a key role in plant defense and could be used as a promising source for biocontrol agents. ${ }^{9}$

A total of 89 fungi were obtained from the roots, stems, leaves, and seeds of $P$. notoginseng by Youkun Zheng et al., ${ }^{10}$

${ }^{a}$ School of Life Science and Biopharmaceutics, Shenyang Pharmaceutical University, Shenyang, 110016, People's Republic of China. E-mail: zhangyxzsh@163.com; Fax: +86-24-23986576; Tel: +86-24-23986576

${ }^{b}$ Department of Pharmacology, Yale University School of Medicine, New Haven, CT 06520, USA

${ }^{c}$ Yunnan Provincial Academy of Science and Technology, Kunming, 650051, People's Republic of China

$\dagger$ Electronic supplementary information (ESI) available. See DOI: 10.1039/c7ra07060h

\$ These authors contributed equally to this work.
$63.4 \%$ exhibited activity against at least one of the pathogens tested. Specifically endophytic Trichoderma gamsii secreted volatile organic compounds with antagonistic effects on the pathogenic root-rot fungi of $P$. notoginseng. ${ }^{11}$ Furthermore, many endophytic fungi are capable of synthesizing various bioactive compounds that are used today as therapeutic agents against numerous diseases. ${ }^{12}$ The endophytic fungus Taxomyces andreanae provided a novel and promising approach to produce the compound paclitaxel. ${ }^{13}$ The endophytic Alternaria sp. obtained from Sabina vulgaris could produce podophyllotoxin ${ }^{\mathbf{1 4}}$ which is a well-known aryltetralin lignan with potent anticancer, antiviral, antioxidant, antibacterial, immunostimulation and anti-rheumatic properties. Entrophospora infrequens, obtained from plant Nothapodytes foetida, has the ability to produce camptothecin (CPT).$^{15}$ Two famous CPT derivatives, hycamtin (topotecan) and camptostar (irinotecan), have already been in clinical use to overcome ovarian, small lung refractory ovarian and other cancers all over the world. ${ }^{\mathbf{1 6}}$

Known as one of the most versatile "body defense factories", Penicillum janthinellum, can produce gibberellins ${ }^{17}$ that are known for its plant protection effects. It also produces emodin, ${ }^{18}$ fumitremorgin $\mathrm{C}^{19}{ }^{19}$ hadacidin, ${ }^{20}$ and epipolythiodioxopiperazine (ETP) alkaloids ${ }^{21}$ that are known to have good antitumor activities. Here we report the investigation of metabolites produced by an endophytic strain, Penicillium sp. 
SYP-ZL1031, that was isolated from the root of a healthy threeyear-old $P$. notoginseng. Using NMR and MS data analysis, along with Mosher's method based on MTPA esters, five new compounds 1-5 named brefeldin E1-E5 and brefeldin A (BFA, 6), brefeldin A 7-O-acetate (7), mycotoxins (8-9), mangrovamides A (10) were identified. BFA is a 16-membered ring macrolide antibiotic initially isolated from Penicillium decumbens. $^{22}$ It has been successively separated from $P$. simplicissimum $^{23}{ }^{23}$. cyaneum $^{24}$ and Eupenicillium brefeldianum. $^{25}$ BFA has been used as a leading anticancer agent, ${ }^{26}$ which interferes with the traffic endoplasmic reticulum (ER) to the Golgi membrane, causing the disassembly and redistribution of Golgi apparatus proteins in eukaryotic cells. ${ }^{27,28}$ In addition, BFA showed activity against neuroendocrine tumor and prostatic cancer cells via a p53-independent mechanism..$^{26,29,30}$ Here we introduce and describe an endophytic fungus, Penicillium sp., that produces BFA series compounds. This study aims to screen new or known active compounds with biological cytotoxic, antiviral, antimicrobial activities.

\section{Results and discussion}

The investigation of metabolites produced by an endophytic strain, Penicillium sp. SYP-ZL1031. SYP-ZL1031 was cultured at $28{ }^{\circ} \mathrm{C}$ in rice. From the ethyl acetate extracts of the fermented broths, ten compounds including five new compounds (1-5) and five known compounds, BFA (6), brefeldinA 7-O-acetate (7), mycotoxins (8-9) and mangrovamides A (10) (Fig. 1) were isolated. They were all obtained from endophytic strain for the first time.

\section{Structural elucidation of the new compounds (1-5)}

Using a combination of HR-ESI-MS and NMR spectroscopy, a colorless oil, brefeldin E1 (1), was analyzed for $\mathrm{C}_{16} \mathrm{H}_{22} \mathrm{O}_{6}$. The $\mathrm{UV} \lambda_{\max }$ at $203 \mathrm{~nm}$ indicated the presence of an $\alpha, \beta$-unsaturated double bond. The absorption bands at 3420 (strong wide wave),
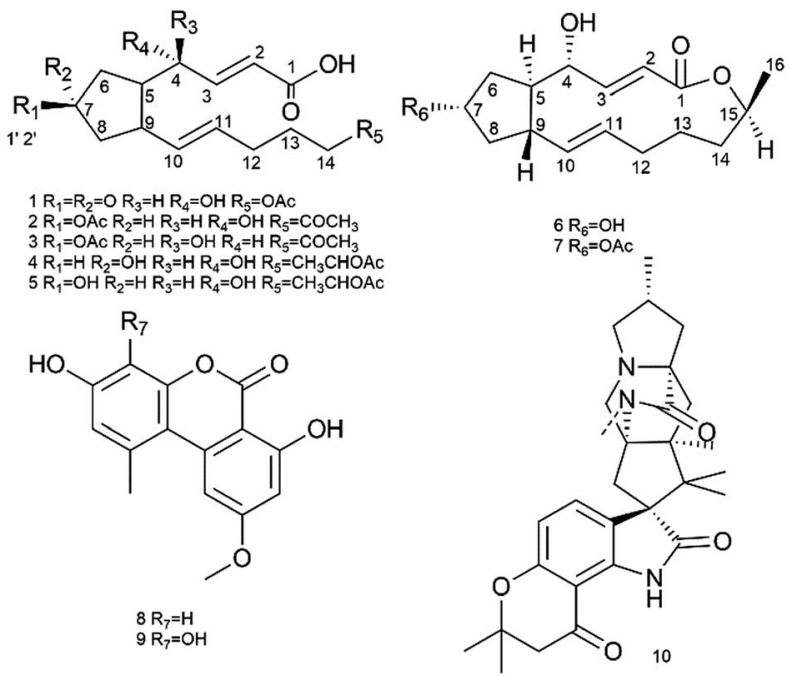

Fig. 1 Chemical structures of compounds 1-10.
1737 and $1657 \mathrm{~cm}^{-1}$ in IR spectrum suggested the presence of hydroxyl carboxylic acid carbonyl, and $\alpha, \beta$-unsaturated ketone carbonyl functionalities (S46†). The circular dichroism (CD) curve (S51-A $\dagger$ ) of 1 showed a positive Cotton Effect (CE) at $\Delta \varepsilon_{208}$ 4.64, a negative $\mathrm{CE}$ at $\Delta \varepsilon_{294}-2.03$. The ${ }^{1} \mathrm{H}$ and ${ }^{13} \mathrm{C}-\mathrm{NMR}$ spectra (S1-S2 $\uparrow$ and Table 1 ) together with HSQC data (S4 $\dagger$ ) of 1 showed the presence of one methyl $\left[\delta_{\mathrm{H}} 2.03 \mathrm{~s}\right.$ and $\left.\delta_{\mathrm{C}} 21.0\right]$, five methylenes, seven methines, including one oxygenated $\left[\delta_{\mathrm{H}} 4.38 \mathrm{brs} \delta_{\mathrm{C}}\right.$ 69.7] and four olefins [ $\delta_{\mathrm{H}} 6.61 \mathrm{dd}(J=16.1,5.0 \mathrm{~Hz}, \mathrm{H}-3), 6.01 \mathrm{~d}(J$ $=16.1, \mathrm{~Hz}, \mathrm{H}-2), 5.60 \mathrm{dt}(J=15.2,6.8 \mathrm{~Hz}, \mathrm{H}-11), 5.46 \mathrm{dd}(J=$ $\left.15.2,8.3 \mathrm{~Hz}, \mathrm{H}-10) ; \delta_{\mathrm{C}} 146.3,127.1,132.6,133.8\right]$, and three carbonyls $\left(\delta_{\mathrm{C}} 220.2,174.9,173.1\right)$. The planar structure of 1 (Fig. 2A) was established by the 2D NMR data. A five-membered ring was deduced by the COSY $(\mathrm{S} 3 \dagger)$ correlations $(\mathrm{H}-5 / \mathrm{H}-6, \mathrm{H}-8$ / $\mathrm{H}-9)$ and the HMBC (S5 $\dagger$ ) correlations from $\mathrm{H}-6$ to $\mathrm{C}-7$ and $\mathrm{H}-8$ to C-7. The additional COSY correlations $(\mathrm{H}-5 / \mathrm{H}-4 / \mathrm{H}-3 / \mathrm{H}-2)$ and HMBC correlations from $\mathrm{H}-4$ to $\mathrm{C}-9, \mathrm{C}-3, \mathrm{C}-2$ and $\mathrm{H}-3$ to $\mathrm{C}-1$ constructed fragment A. Fragment B from C-9 to C-16 was constructed by the COSY correlations from $\mathrm{H}-9$ to $\mathrm{H}-14$ and HMBC correlations from $\mathrm{H}-14$ and $\mathrm{H}-16$ to $\mathrm{C}-15$. These two fragments were further connected to the five-membered ring via C-5 and C-9, as evidenced by the HMBC correlations from $\mathrm{H}-9$ to C-11, and from H-4 to C-9. The double bonds in $\Delta_{2,3}$ and $\Delta_{10,11}$ were assigned to be $E$ geometry on the basis of the coupling constants $\left(J_{2-3}=16.1, J_{10-11}=15.2 \mathrm{~Hz}\right)$. The relative configurations of the $\mathrm{H}-5$ and $\mathrm{H}-9$ to $\mathrm{H}-4$ were determined based on the coupling constants and NOESY (S6†) correlations. The method of homonuclear decoupling ${ }^{31,32}$ is applied to obtain the coupling constants $\mathrm{H}-4 / \mathrm{H}-5\left(J_{4-5}=1.4 \mathrm{~Hz}\right)$. We can infer from the coupling constant $\mathrm{H}-4 / \mathrm{H}-5\left(J_{4-5}=1.4 \mathrm{~Hz}\right)$ that the angle between $\mathrm{H}-4$ and $\mathrm{H}-5$ is about 90 degree and $\mathrm{H}-4 / \mathrm{H}-5$ were on transorientation of the molecule. ${ }^{33,34}$ On the other hand, based on the NOESY ( $66^{\dagger}$ ) correlations, $\mathrm{H}-9$ did not have a correlation with $\mathrm{H}$ 5 , but instead with $\mathrm{H}-4$, demonstrating that $\mathrm{H}-9 / \mathrm{H}-5$ were on trans-orientation of the molecule, while $\mathrm{H}-9 / \mathrm{H}-4$ were on cisorientation. ${ }^{35}$ The absolute configuration of compound 1 was determined through Mosher's method. ${ }^{36}$ The $\Delta \delta^{S R}$ values between 1a and 1b ( $R$ - and $S$-MTPA esters of 1 on $\mathrm{OH}-4$, respectively) were positive for $\mathrm{H}-2 / 3$ and negative for $\mathrm{H}-5 / 6 / 8$ (Fig. 3 and $S 53^{\mathrm{a}} \dagger$ ), which indicated the $4 S$ configuration.

Brefeldin E2 (2) and E3 (3) were extracted as colorless oils. Using HR-ESI-MS and NMR data, it was deduced that both had formula of $\mathrm{C}_{18} \mathrm{H}_{26} \mathrm{O}_{6}$. The $\mathrm{CD}$ curve (S51-B $\dagger$ ) of 2 showed a positive $\mathrm{CE}$ at $\Delta \varepsilon_{208} 5.57$, a negative $\mathrm{CE}$ at $\Delta \varepsilon_{195}-3.32$. The $\mathrm{CD}$ curve (S51- $\mathrm{C}^{\dagger}$ ) of 3 showed two positive $\mathrm{CE}$ at $\Delta \varepsilon_{197} 0.50$ and $\Delta \varepsilon_{223}$ 1.05. The ${ }^{1} \mathrm{H}$ and ${ }^{13} \mathrm{C}-\mathrm{NMR}$ data of 2 and 3 (S8-S9, S15$\mathrm{S} 16 \dagger$ and Table 1) were similar to those of $\mathbf{1}$, and the molecular weight differed by 28 Dalton from 1 . The major differences in NMR data between compounds 2, 3 and compound 1 were found to be the presence of the $O$-acetyl group in C-7 $\left(\delta_{\mathrm{C}} 172.9 /\right.$ 172.8 and 21.3/21.3, which were assigned to $\mathrm{C}-1^{\prime}$ and $\mathrm{C}-2^{\prime}$ in 2 and 3). In addition, the $O$-acetyl group in $\mathrm{C}-14$ of compound 1 was replaced by a ketone group in compound 2 and 3 . The HMBC (S12 and S19†) correlation from H-7 and $\mathrm{H}-13\left(\delta_{\mathrm{H}} 5.05 /\right.$ $5.05 \mathrm{~m}, 2.02 / 2.01 \mathrm{~m})$ to $\mathrm{C}-1^{\prime}$ and $\mathrm{C}-15\left(\delta_{\mathrm{C}} 172.9 / 172.8 / 212.2 /\right.$ 212.1) confirmed the planar structure of $2 / 3$. The relative configurations of the $\mathrm{H}-5, \mathrm{H}-9$ and $\mathrm{H}-4$ in 2 were using the same 
Table $1{ }^{1} \mathrm{H}(600 \mathrm{MHz})$ and ${ }^{13} \mathrm{C}(150 \mathrm{MHz})$ NMR spectroscopic data of compounds $1-5$ in $\mathrm{CD}_{3} \mathrm{OD}$

\begin{tabular}{|c|c|c|c|c|c|c|c|c|c|c|}
\hline \multirow[b]{2}{*}{ Pos } & \multicolumn{2}{|l|}{1} & \multicolumn{2}{|l|}{2} & \multicolumn{2}{|l|}{3} & \multicolumn{2}{|l|}{4} & \multicolumn{2}{|l|}{5} \\
\hline & $\delta_{\mathrm{H}}(J$ in $\mathrm{Hz})$ & $\delta_{\mathrm{C}}$ & $\delta_{\mathrm{H}}(J$ in $\mathrm{Hz})$ & $\delta_{\mathrm{C}}$ & $\delta_{\mathrm{H}}(J$ in $\mathrm{Hz})$ & $\delta_{\mathrm{C}}$ & $\delta_{\mathrm{H}}(J$ in $\mathrm{Hz})$ & $\delta_{\mathrm{C}}$ & $\delta_{\mathrm{H}}(J$ in $\mathrm{Hz})$ & $\delta_{\mathrm{C}}$ \\
\hline 1 & & $174.9 \mathrm{C}$ & & $175.4 \mathrm{C}$ & & $171.4 \mathrm{C}$ & & $172.9 \mathrm{C}$ & & $172.9 \mathrm{C}$ \\
\hline 2 & $6.01, \mathrm{~d}(16.1)$ & $127.1 \mathrm{CH}$ & $5.99, \mathrm{~d}(15.5)$ & $126.7 \mathrm{CH}$ & $5.99, \mathrm{~d}(15.5)$ & $122.2 \mathrm{CH}$ & $5.98, \mathrm{~d}(15.6)$ & $124.9 \mathrm{CH}$ & $5.99, \mathrm{~d}(15.5)$ & $128.0 \mathrm{CH}$ \\
\hline 3 & $\begin{array}{l}6.61, \mathrm{dd} \\
(5.0,16.1)\end{array}$ & $146.3 \mathrm{CH}$ & $\begin{array}{l}6.67, \mathrm{dd} \\
(5.1,15.5)\end{array}$ & $147.6 \mathrm{CH}$ & $\begin{array}{l}6.89, \mathrm{dd} \\
(4.3,15.5)\end{array}$ & $152.3 \mathrm{CH}$ & $6.75, \mathrm{~d}(15.6)$ & $149.5 \mathrm{CH}$ & $\begin{array}{l}6.58, \mathrm{dd} \\
(5.3,15.5)\end{array}$ & $146.6 \mathrm{CH}$ \\
\hline 4 & 4.38, brs & $69.7 \mathrm{CH}$ & 4.22 , brs & $70.9 \mathrm{CH}$ & 4.24 , brs & $71.2 \mathrm{CH}$ & $4.20, \mathrm{~m}$ & $71.4 \mathrm{CH}$ & $4.19, \mathrm{~m}$ & $71.5 \mathrm{CH}$ \\
\hline 5 & $2.12, \mathrm{~m}$ & $49.2 \mathrm{CH}$ & $1.92, \mathrm{~m}$ & $50.8 \mathrm{CH}$ & $1.94, \mathrm{~m}$ & $50.6 \mathrm{CH}$ & $1.95, \mathrm{~m}$ & $50.5 \mathrm{CH}$ & $1.95, \mathrm{~m}$ & $50.6 \mathrm{CH}$ \\
\hline \multirow[t]{2}{*}{6} & $\begin{array}{l}2.41, \mathrm{dd} \\
(10.4,18.1)\end{array}$ & $46.6 \mathrm{CH}_{2}$ & $1.91, \mathrm{~m}$ & $33.4 \mathrm{CH}_{2}$ & $1.90, \mathrm{~m}$ & $33.9 \mathrm{CH}_{2}$ & $1.84, \mathrm{~m}$ & $35.9 \mathrm{CH}_{2}$ & $1.86, \mathrm{~m}$ & $35.8 \mathrm{CH}_{2}$ \\
\hline & $2.13, \mathrm{~m}$ & & $1.67, \mathrm{~m}$ & & $1.68, \mathrm{~m}$ & & $1.50, \mathrm{~m}$ & & $1.58, \mathrm{~m}$ & \\
\hline 7 & & $220.2 \mathrm{C}$ & $5.05, \mathrm{~m}$ & $76.9 \mathrm{CH}$ & $5.05, \mathrm{~m}$ & $76.8 \mathrm{CH}$ & $4.19, \mathrm{~m}$ & $73.0 \mathrm{CH}$ & $4.17, \mathrm{~m}$ & $73.1 \mathrm{CH}$ \\
\hline \multirow[t]{2}{*}{8} & $\begin{array}{l}2.27, \mathrm{dd} \\
(11.2,18.7)\end{array}$ & $38.7 \mathrm{CH}_{2}$ & $2.28, \mathrm{~m}$ & $40.8 \mathrm{CH}_{2}$ & $2.29, \mathrm{~m}$ & $40.9 \mathrm{CH}_{2}$ & $2.14, \mathrm{~m}$ & $43.8 \mathrm{CH}_{2}$ & $2.13, \mathrm{~m}$ & $43.7 \mathrm{CH}_{2}$ \\
\hline & $\begin{array}{l}2.20, \mathrm{dd} \\
(7.6,18.7)\end{array}$ & & $1.51, \mathrm{~m}$ & & $1.52, \mathrm{~m}$ & & $1.43, \mathrm{~m}$ & & $1.42, \mathrm{~m}$ & \\
\hline 9 & $2.87, \mathrm{~m}$ & $43.0 \mathrm{CH}$ & $2.49, \mathrm{~m}$ & $44.5 \mathrm{CH}$ & $2.49, \mathrm{~m}$ & $44.6 \mathrm{CH}$ & $2.45, \mathrm{~m}$ & $44.7 \mathrm{CH}$ & $2.45, \mathrm{~m}$ & $44.6 \mathrm{CH}$ \\
\hline 10 & $\begin{array}{l}5.46, \mathrm{dd} \\
(8.3,15.2)\end{array}$ & $133.8 \mathrm{CH}$ & $\begin{array}{l}5.37, \mathrm{dd} \\
(8.4,15.2)\end{array}$ & $135.5 \mathrm{CH}$ & $\begin{array}{l}5.36, \mathrm{dd} \\
(8.5,15.3)\end{array}$ & $135.4 \mathrm{CH}$ & $\begin{array}{l}5.39, \mathrm{dd} \\
(7.9,15.2)\end{array}$ & $135.8 \mathrm{CH}$ & $\begin{array}{l}5.39, \mathrm{dd} \\
(7.5,15.2)\end{array}$ & $135.9 \mathrm{CH}$ \\
\hline 11 & $\begin{array}{l}5.60, \mathrm{dt} \\
(6.8,15.2)\end{array}$ & $132.6 \mathrm{CH}$ & $\begin{array}{l}5.45, \mathrm{dt} \\
(6.7,15.2)\end{array}$ & $131.7 \mathrm{CH}$ & $\begin{array}{l}5.45, \mathrm{dd} \\
(6.7,15.3)\end{array}$ & $131.9 \mathrm{CH}$ & $\begin{array}{l}5.44, \mathrm{dt} \\
(6.3,15.2)\end{array}$ & $131.5 \mathrm{CH}$ & $\begin{array}{l}5.43, \mathrm{dt} \\
(6.2,15.2)\end{array}$ & $131.4 \mathrm{CH}$ \\
\hline 12 & $\begin{array}{l}2.15, \mathrm{~m} \\
2.15, \mathrm{~m}\end{array}$ & $30.0 \mathrm{CH}_{2}$ & $\begin{array}{l}1.62, \mathrm{~m} \\
1.62, \mathrm{~m}\end{array}$ & $24.8 \mathrm{CH}_{2}$ & $\begin{array}{l}1.62, \mathrm{~m} \\
1.62, \mathrm{~m}\end{array}$ & $24.7 \mathrm{CH}_{2}$ & $\begin{array}{l}2.00, \mathrm{~m} \\
2.00, \mathrm{~m}\end{array}$ & $33.4 \mathrm{CH}_{2}$ & $\begin{array}{l}2.02, \mathrm{~m} \\
2.02, \mathrm{~m}\end{array}$ & $33.4 \mathrm{CH}_{2}$ \\
\hline 13 & $\begin{array}{l}1.72, \mathrm{~m} \\
1.72, \mathrm{~m}\end{array}$ & $29.6 \mathrm{CH}_{2}$ & $\begin{array}{l}2.02, \mathrm{~m} \\
2.02, \mathrm{~m}\end{array}$ & $33.0 \mathrm{CH}_{2}$ & $\begin{array}{l}2.01, \mathrm{~m} \\
2.01, \mathrm{~m}\end{array}$ & $33.0 \mathrm{CH}_{2}$ & $\begin{array}{l}1.38, \mathrm{~m} \\
1.38, \mathrm{~m}\end{array}$ & $26.6 \mathrm{CH}_{2}$ & $\begin{array}{l}1.37, \mathrm{~m} \\
1.37, \mathrm{~m}\end{array}$ & $26.6 \mathrm{CH}_{2}$ \\
\hline 14 & $\begin{array}{l}4.08, \mathrm{t}(6.6) \\
4.08, \mathrm{t}(6.6)\end{array}$ & $65.1 \mathrm{CH}_{2}$ & $\begin{array}{l}2.48, \mathrm{t}(7.3) \\
2.48, \mathrm{t}(7.3)\end{array}$ & $43.7 \mathrm{CH}_{2}$ & $\begin{array}{l}2.48, \mathrm{t}(7.4) \\
2.48, \mathrm{t}(7.4)\end{array}$ & $43.7 \mathrm{CH}_{2}$ & $\begin{array}{l}1.57, \mathrm{~m} \\
1.57, \mathrm{~m}\end{array}$ & $36.5 \mathrm{CH}_{2}$ & $\begin{array}{l}1.59, \mathrm{~m} \\
1.50, \mathrm{~m}\end{array}$ & $36.6 \mathrm{CH}_{2}$ \\
\hline 15 & & $173.1 \mathrm{C}$ & & $212.2 \mathrm{C}$ & & $212.1 \mathrm{C}$ & $4.87, \mathrm{~m}$ & $72.5 \mathrm{CH}$ & $4.87, \mathrm{~m}$ & $72.5 \mathrm{CH}$ \\
\hline $\begin{array}{l}16 \\
1^{\prime} / 17\end{array}$ & $2.03, \mathrm{~s}$ & $21.0 \mathrm{CH}_{3}$ & $2.13, \mathrm{~s}$ & $\begin{array}{l}30.1 \mathrm{CH}_{3} \\
172.9 \mathrm{C}\end{array}$ & $2.13, \mathrm{~s}$ & $\begin{array}{l}30.0 \mathrm{CH}_{3} \\
172.8 \mathrm{C}\end{array}$ & $1.20, \mathrm{~d}(6.2)$ & $\begin{array}{l}20.4 \mathrm{CH}_{3} \\
171.2 \mathrm{C}\end{array}$ & $1.20, \mathrm{~d}(6.2)$ & $\begin{array}{l}20.4 \mathrm{CH}_{3} \\
173.0 \mathrm{C}\end{array}$ \\
\hline $2^{\prime} / 18$ & & & $1.99, \mathrm{~s}$ & $21.3 \mathrm{CH}_{3}$ & $2.00, \mathrm{~s}$ & $21.3 \mathrm{CH}_{3}$ & $2.00, \mathrm{~s}$ & $21.4 \mathrm{CH}_{3}$ & $2.00, \mathrm{~s}$ & $21.4 \mathrm{CH}_{3}$ \\
\hline
\end{tabular}

method as compound 1 . The coupling constants $\mathrm{H}-4 / \mathrm{H}-5\left(J_{4-5}=\right.$ $0.9 \mathrm{~Hz}$ ) deduced the angle between $\mathrm{H}-4 / \mathrm{H}-5$ was about to 90 degree and $\mathrm{H}-4 / \mathrm{H}-5$ were on trans-orientation of the molecule. $^{33,34}$ The NOESY $(\mathrm{S} 13 \dagger)$ correlations revealed that $\mathrm{H}-9 / \mathrm{H}-5$ were on the trans-orientation of the molecule, and $\mathrm{H}-9 / \mathrm{H}-4$ were on the cis-orientation. The other key NOESY (S13†) of compound 2 were observed between $\mathrm{H}-7, \mathrm{H}-5$ and $\mathrm{H}-9 . \mathrm{H}-7$ did not have a correlation with $\mathrm{H}-9$, but with $\mathrm{H}-5$, demonstrated that $\mathrm{H}-7 / \mathrm{H}-9$ were on a trans-orientation of the molecule while $\mathrm{H}-7 / \mathrm{H}-5$ were on the cis-orientation. The relative configurations (S20 $\dagger$ ) of the $\mathrm{H}-5, \mathrm{H}-9$ and $\mathrm{H}-4$ in 3 were different from compound 1. The coupling constants between $\mathrm{H}-4$ and $\mathrm{H}-5\left(J_{4-5}\right.$
$=3.8 \mathrm{~Hz}$ ) were calculated using homonuclear decoupling ${ }^{31,32}$ method. The coupling constant $J_{4-5}=3.8 \mathrm{~Hz}$ indicated that the angle between $\mathrm{H}-4$ and $\mathrm{H}-5$ is about 0 or 180 degrees and $\mathrm{H}-4 / \mathrm{H}-$ 5 were on cis-orientation of the molecule. ${ }^{33,34}$ Based on the NOESY correlations, $\mathrm{H}-9$ had no correlation with $\mathrm{H}-5$ and $\mathrm{H}-4$, which demonstrated $\mathrm{H}-9 / \mathrm{H}-5$ were on the trans-orientation of the molecule, and $\mathrm{H}-5 / \mathrm{H}-4$ were on the cis-orientation. The relative configurations of $\mathrm{H}-7, \mathrm{H}-5$ and $\mathrm{H}-9$ in 3 were the same as compound 2 . The absolute configurations of compounds 2 and 3 were also determined based on Mosher's method (Fig. 3 and S53 $3^{\mathrm{b}, \mathrm{c}}$ ). The $\Delta \delta^{S R}$ values between 2a and $2 \mathbf{b}(R$ - and $S$-MTPA esters of 2 on $\mathrm{OH}-4$, respectively) were negative for $\mathrm{H}-5 / \mathrm{H}-6$ and
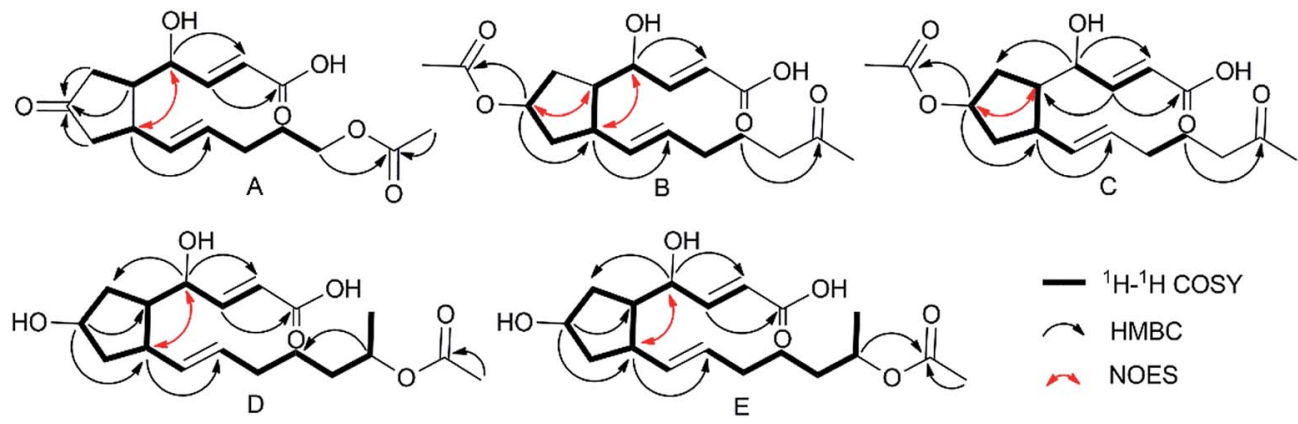

Fig. 2 Key 2D NMR correlations of 1 (A), 2 (B), 3 (C), 4 (D), 5 (E). 

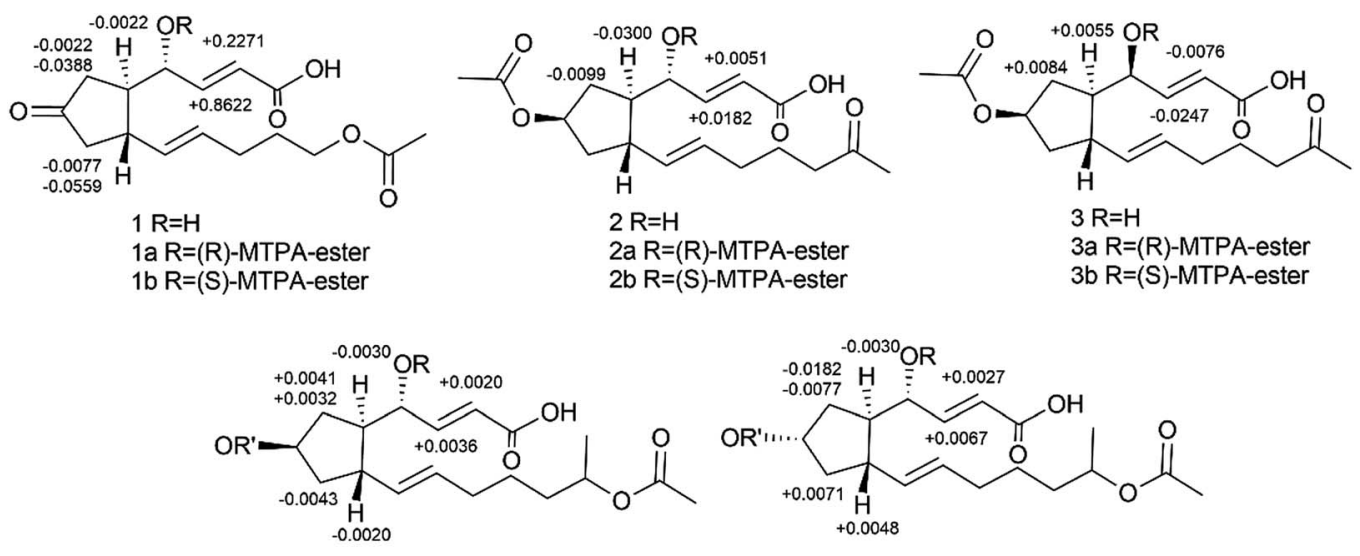

$4 \mathrm{R} / \mathrm{R}^{\prime}=\mathrm{H}$

4a R/R'=(R)-MTPA-ester

$4 \mathrm{~b} R / \mathrm{R}^{\prime}=(\mathrm{S})$-MTPA-ester

$5 \mathrm{R} / \mathrm{R}^{\prime}=\mathrm{H}$

5 a R/R'=(R)-MTPA-ester

$5 \mathrm{~b}$ R/R'=(S)-MTPA-ester

Fig. $3 \Delta \delta$ values $\left(\delta_{\mathrm{b}}-\delta_{\mathrm{a}}\right.$ in ppm) obtained for the MTPA esters of compounds $1-5$

positive for $\mathrm{H}-2 / \mathrm{H}-3$ (Fig. 3 and $\mathrm{S} 53^{\mathrm{b}} \dagger$ ), which indicated the $4 S$ configuration. The opposite result in compound $\mathbf{3}$ where $\mathbf{3 a}$ and 3 b ( $R$ - and $S$-MTPA esters of 3 on $\mathrm{OH}-4$, respectively) were positive for $\mathrm{H}-5 / \mathrm{H}-6$ and negative for $\mathrm{H}-2 / \mathrm{H}-3$ (Fig. 3 and $\mathrm{S} 53^{\mathrm{C}} \dagger$ ), indicated the $4 R$ configuration.

Brefeldin E4 (4) and E5 (5) were extracted as a colorless oil and assigned the same molecular formulas $\mathrm{C}_{18} \mathrm{H}_{28} \mathrm{O}_{6}$ using HRESI-MS analysis. The CD curve (S51-D $\dot{\dagger}$ ) of 4 showed a positive $\mathrm{CE}$ at $\Delta \varepsilon_{210}$ 3.74. The CD curve (S51-E $\dagger$ ) of 5 showed a positive $\mathrm{CE}$ at $\Delta \varepsilon_{207}$ 4.76, a negative CE at $\Delta \varepsilon_{194}-1.59$. Detailed analysis of 1D NMR data (S22-S23, S29-S30 $\dagger$ and Table 1) indicated that compounds $\mathbf{4}$ and $\mathbf{5}$ showed a striking resemblance to compounds 1, respectively, except for the presence of C-15 $\left(\delta_{\mathrm{C}}\right.$ $72.5 / 72.5$ in 4/5), C-16 $\left(\delta_{\mathrm{C}} 20.4 / 20.4\right.$ in 4/5), and the C-7 ketone of compound 1 was replaced to be a hydroxyl group in compounds 4 and 5. The HMBC $(\mathrm{S} 26 \dagger)$ correlation from $\mathrm{H}-15\left(\delta_{\mathrm{H}} 4.87 \mathrm{~m}\right)$ to C$13\left(\delta_{\mathrm{C}} 26.6\right)$ confirmed the planar structure of 4 . And the HMBC $(\mathrm{S} 33 \dagger)$ correlation from $\mathrm{H}-15\left(\delta_{\mathrm{H}} 4.87 \mathrm{~m}\right)$ to $\mathrm{C}-17\left(\delta_{\mathrm{C}} 173.0\right)$ confirmed the planar structure of $\mathbf{5}$. The relative configuration (S27 and S34†) of the H-5, H-9 and H-4 in compound 4 and 5 were the same to compound $\mathbf{1}$ based on the NOESY correlations and coupling constants $\mathrm{H}-4 / \mathrm{H}-5\left(J_{4-5}=0.4 / 0.8 \mathrm{~Hz}\right.$ in $\left.\left.4 / 5\right)\right)^{33,34} \mathrm{We}$ can infer from the coupling constant $\mathrm{H}-4 / \mathrm{H}-5\left(J_{4-5}=0.4 / 0.8 \mathrm{~Hz}\right.$ in 4/5) that the angle between $\mathrm{H}-4$ and $\mathrm{H}-5$ is about 90 degree and $\mathrm{H}-4 / \mathrm{H}-5$ were on trans-orientation of the molecule. ${ }^{33,34} \mathrm{On}$ the other hand, based on the NOESY (S27 and S34†) correlations, $\mathrm{H}-9$ did not have a correlation with $\mathrm{H}-5$, but instead with $\mathrm{H}-4$, demonstrating that $\mathrm{H}-9 / \mathrm{H}-5$ were on a trans-orientation of the molecule, and $\mathrm{H}-9 / \mathrm{H}-4$ were on the cis-orientation. The absolute stereochemistry of positions C-4 and C-7 of brefeldin E4 (4) and E5 (5) were determined by the application of Mosher's method. ${ }^{37}$ Which suggests $4 S, 7 R$ for compound 4 (Fig. 3 and S53 ${ }^{\mathrm{d}_{\dagger}}$ ) and $4 S, 7 S$ for compound 5 (Fig. 3 and $S 53^{\mathrm{e}} \dagger$ ).

The structures of compounds 6-10 were determined by HRESI-MS and NMR spectroscopy $\left({ }^{1} \mathrm{H}\right.$ and $\left.{ }^{13} \mathrm{C}-\mathrm{NMR}\right)$. BFA (6) and brefeldin A 7-O-acetate (7) were deduced to be very compatible with spectroscopic data found in the literature. ${ }^{38,39}$ The ${ }^{1} \mathrm{H}$ and ${ }^{13} \mathrm{C}$ NMR of compound 8-10 were in good agreement with
alternariol-5-O-methyl ether, ${ }^{40} 3^{\prime}$-hydroxyalternariol-5-O-methyl ether ${ }^{40}$ and mangrovamides $\mathrm{A}^{41}$ respectively. The similar CD profiles and same sign of optical rotations of compound $\mathbf{1 0}$ suggested that the absolute configuration of $\mathbf{1 0}$ was the same as mangrovamides $\mathrm{A}$.

\section{In vitro cytotoxic activity and cell cycle analysis}

The isolated metabolites on cytotoxic and antiviral were evaluated. As shown in the Table 2, it was found that brefeldin E1-E5 (1-5), with the open-ring of macrolide of BFA, and compound 810 displayed low cytotoxicities and antiviral activity respectively. In contrast, the compounds 6-7 were identified as being excellent activity compounds when evaluated against cell lines (293, HepG2, Huh7 and KB), showing an $\mathrm{ID}_{50}$ value from $0.024 \mu \mathrm{M}$ to $0.62 \mu \mathrm{M}$ and antiviral (HCV, HBV) with $\mathrm{ID}_{50}$ value from 0.013 $\mu \mathrm{M}$ to $0.022 \mu \mathrm{M}$, respectively. Both BFA (6) and brefeldin A 7-Oacetate (7) demonstrate the same inhibitory behavior of protein translocation from endoplasmic reticulum to the Golgi. ${ }^{27}$ The life cycle of viral replication also requires this process. Thus, it is not surprising that there is an impact on HCV and HBV. In cancer cell lines, cell cycle arrest is one of the most important strategies used to stop or limit cancer proliferation. ${ }^{42}$ As shown in Table 2, compounds 6-7 markedly suppressed the proliferation of HepG2 cells compared with positive drug LODDC with $\mathrm{ID}_{50}$ values of $0.024 \mu \mathrm{M}$. To explore whether the cytotoxicity of compounds 6-7 was due to cell cycle arrest, we first examined the effect on cell cycle distribution using propidiumiodide (PI) staining with flow cytometry analysis. Compounds 6-7 definitely increased the percentage of HepG2 cells at the S phase in a concentration of $0.072 \mu \mathrm{M}$ and $0.1 \mu \mathrm{M}$ at $48 \mathrm{~h}$ (Fig. 4 and 5). This demonstrated that compounds 6-7 inhibited cell growth via inducing $\mathrm{S}$ phase arrest in $\mathrm{HepG} 2$ cells.

\section{Antimicrobial assay}

The 96-well flat-bottomed assay ${ }^{43}$ was used to study the antimicrobial activity. To better understand the antibacterial activity of the compound 1-10, log-phase bacterial suspensions 
Table 2 Cytotoxic activities and antiviral activities of compounds $1-10^{a}$ against a panel ${ }^{b}$ of cancer cell lines as well as HCV and HBV

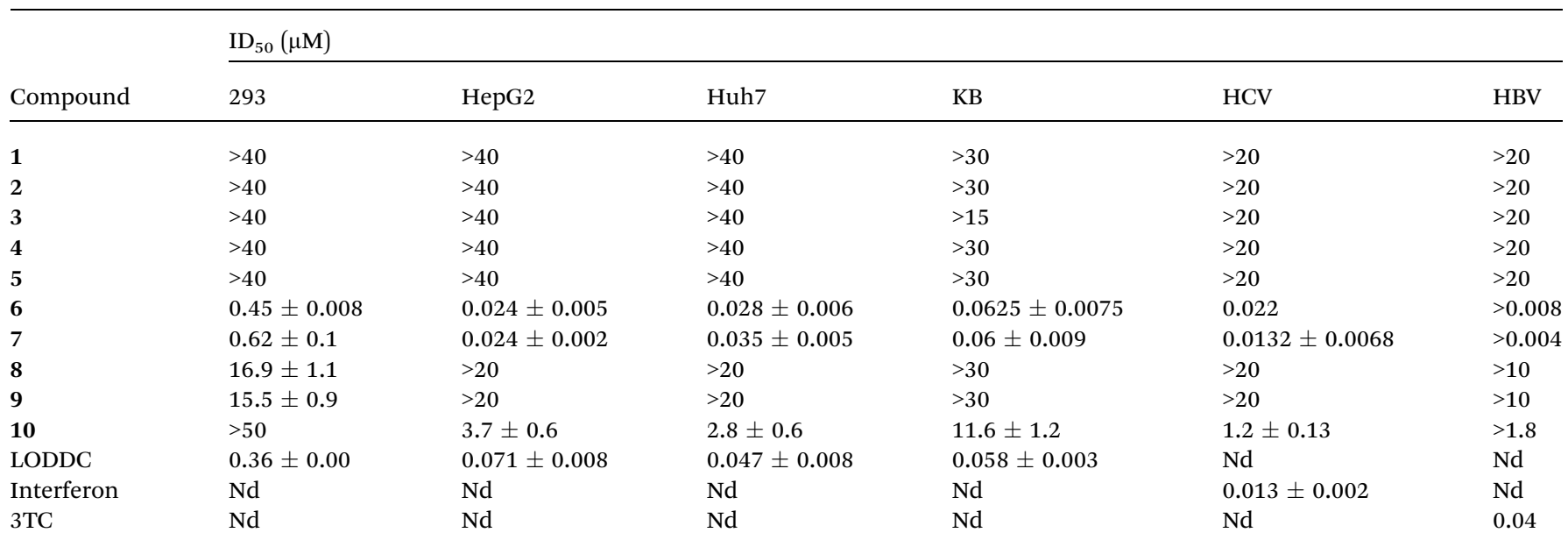

${ }^{a}$ Results are expressed as $\mathrm{ID}_{50}$ values \pm standard deviation in $\mu \mathrm{M}$. LODDC, interferon, 3TC and DMSO were used as positive and negative controls. ${ }^{b}$ Key: $293=$ human renal epithelial cell line; HepG2, Huh7; = human hepatocellular carcinoma cell line; KB = human oral epidermoid carcinoma cell line; $\mathrm{HCV}=$ hepatitis $\mathrm{C}$ virus; $\mathrm{HBV}=$ hepatitis $\mathrm{B}$ virus.

$\mathbf{A}$

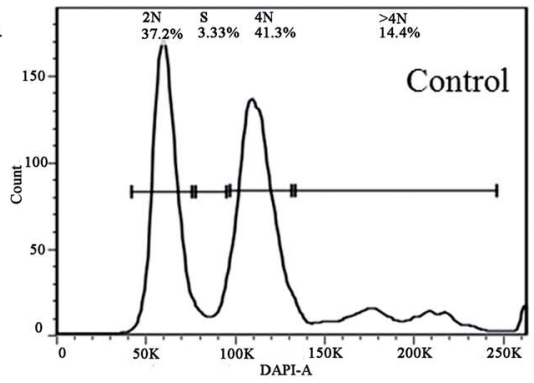

B

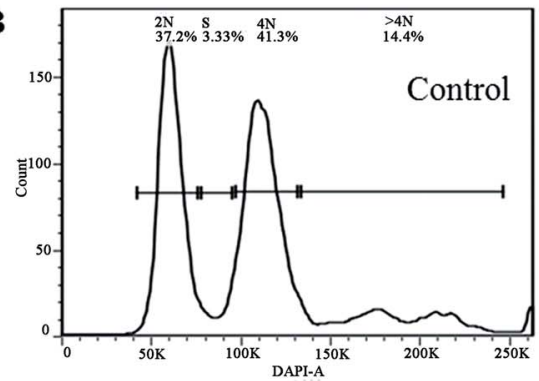

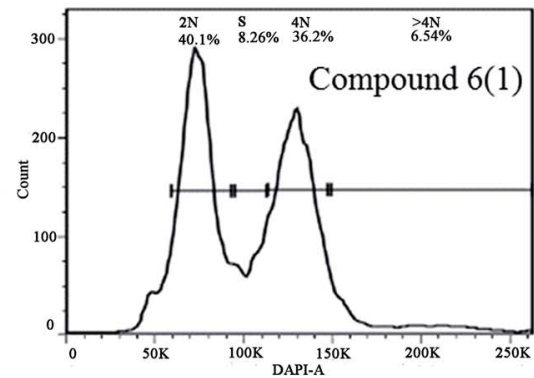
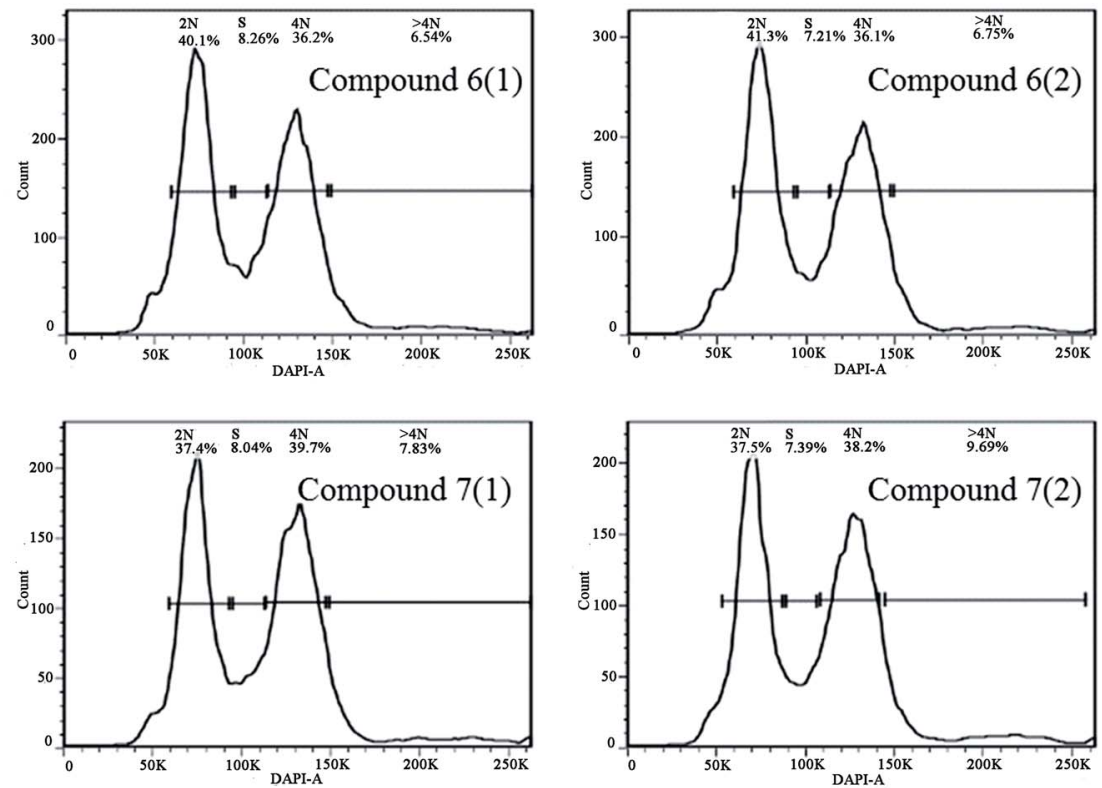

Fig. 4 The flow cytometry histograms of HepG2 cancer cells after treatment with compound 6 (A) and 7 (B) for 30 h. The untreated group was used for negative control.

of Escherichia coli, Staphylococcus aureus, Bacillus cereus, Klebsiella pneumonia and Candida albicans were incubated together with test samples, and the $\mathrm{OD}_{600}$ values were measured after 24 hours. The results showed that the $\mathrm{OD}_{600}$ value of the brefeldin E1 (1), E4-E5 (4-5), brefeldin A (6), brefeldin A 7-O-acetate (7), $3^{\prime}$-hydroxyalternariol-5-O-methyl ether (9) and mangrovamides A (10) groups were significantly lower than those of CK, indicating that compounds 1, 4-7, 9-10 had satisfactory antibacterial activity on at least one of the pathogens tested (Fig. 4A-E). Of those compounds, compound $\mathbf{5}$ showed antibacterial activity to $E$. coli and $S$. aureus. The results indicated that the compound 5 had inhibitory effect on both Gram-negative and Gram- positive bacteria. Moreover, compound 6-7 had strong and broad-spectrum activities against human pathogenic bacteria (Fig. 6A-E).

As endophytic fungi, the metabolic effects of SYP-ZL1031 on pathogenic fungi of $P$. notoginseng were also evaluated. The experimental method is similar to the previously mentioned ${ }^{43}$ before. Compounds 1-2, 4-10 had the ability to inhibit the growth of Cylindrosporium sp. on different levels. Meanwhile, compound 6 and 7 exhibited strong antagonistic activities against three fungal pathogens (Cylindrocarpon didynum, Alternaria panax, Fusarium solani) that can cause root-rot disease in Panax notoginseng (Fig. 7F-H). The results suggest that SYP- 


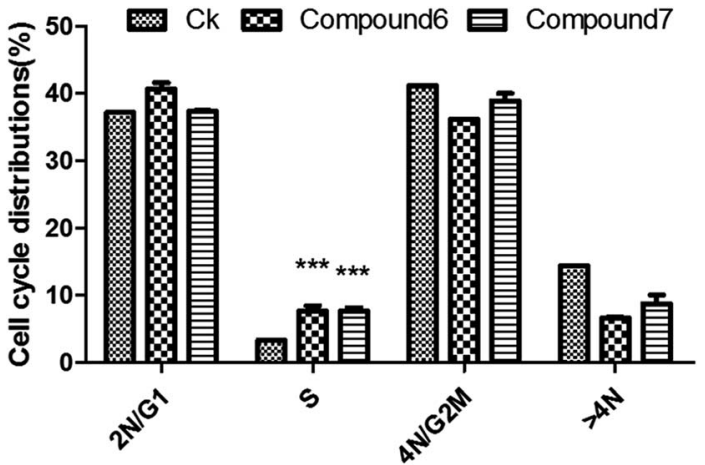

Fig. 5 Cell cycle distribution in HepG2 cells treated with compounds $6-7$. Values are \% events. ${ }^{*} p<0.05$ between drug-treated and control group. Data are mean \pm SD of two independent experiments.

ZL1031 endophytic fungi may be a potential candidate for the metabolites of bioactive compounds, and has the potential to be used as a biological control agent against root-rot disease of $P$. notoginseng.

\section{Structure-activity relationship}

Structure-activity relationship was also discussed between compounds 1-7. BFA series new compounds 1-5, are the ringopened BFA seco-acid. By comparing compounds 1-5 and compounds 6-7, the presence of ring-opened reduced the biological activities against all tested cancer cell lines, virus and pathogenic bacteria/fungi (Table 2, Fig. 6 and 7), which revealed that the conformational rigidity of 13-membered lactone in compounds 6-7 had a great influence on their antitumor, antiviral and antimicrobial potency. Furthermore, C-7 hydroxyl group (compound 6) may be a preferred substituent groups than that of acetyl group (compound 7), for its stronger biological activities according to the $\mathrm{ID}_{50}$ values of cancer cell lines. Compounds 1-5 had the same skeleton apart from the type of substituent groups at C-4 and C-7. A comparison of the antimicrobial data between $\mathbf{4}$ and 5 indicated that the C-7S configuration in compound $\mathbf{5}$ showed significant inhibition of pathogenic bacteria/fungi growth. The results revealed that difference in configuration at stereocenter $\mathrm{C} 7$ showed different antimicrobial activities.

\section{Plausible biosynthetic pathways}

Our isolation of compounds 1-7 raises interesting questions about their biosynthesis. BFA (6), known as a 16-membered ring macrolide antibiotic, ${ }^{22}$ belongs to the polyketides group which constitute a large class of natural products with similar biosynthetic grounds. ${ }^{44}$ The basic carbon skeleton of BFA series compounds might be derived from an acetate starter group, with malonate acting as the chain extender. ${ }^{43}$ The molecules have then, in some cases, been made by decarboxylation/ hydroxylation/aldol cyclization/enolization reactions, which were likely to be the precursors of BFA series compounds. The plausible biosynthetic pathways of 1-7 are shown in (S52 $\dagger$ ).

The structures of compounds 1-7 could be explained as being derived from poly- $\beta$-keto chains, formed by coupling of acetic acid (C2) units via condensation reactions. ${ }^{44}$ The formation of the poly- $\beta$-keto chain could be envisaged as a series of Claisen reactions. Two molecules of acetyl-CoA could participate in a Claisen condensation giving acetoacetyl-CoA, and this reaction could be repeated to generate a poly- $\beta$-keto ester of

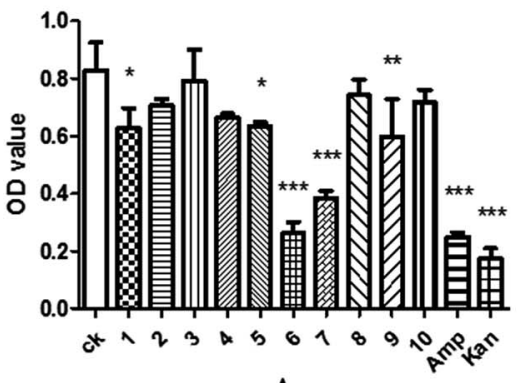

A

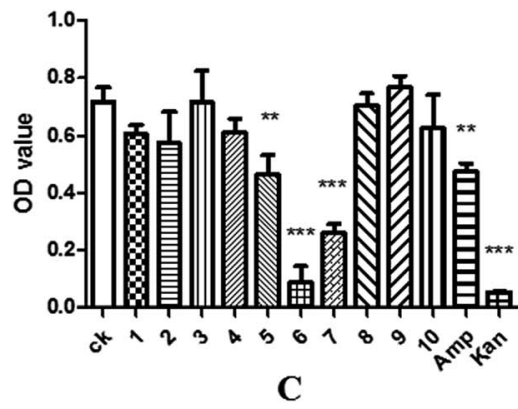

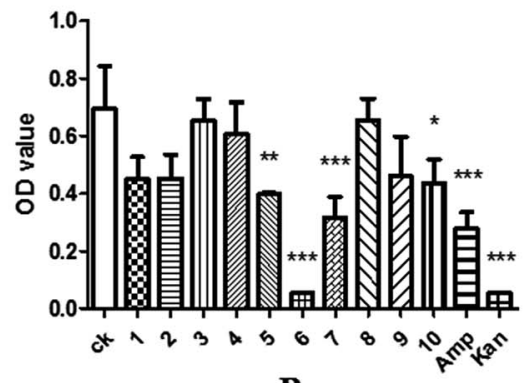

B

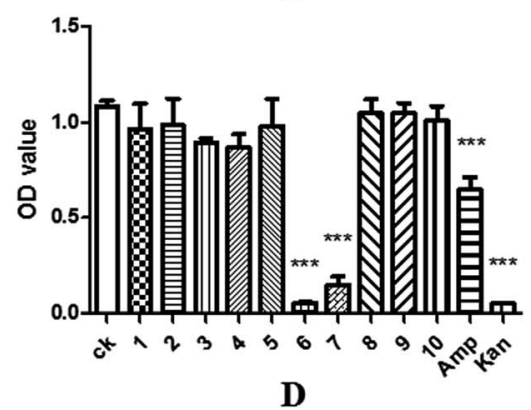

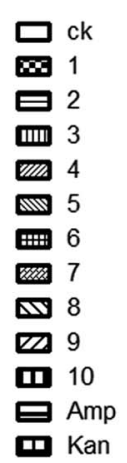

Ean

Fig. 6 Antibacterial activities of compounds 1-10 against E. coli (A), S. aureus (B), B. cereus (C), K. pneumonia (D); ampicillin (Amp) and kanamycin (Kan), were used as positive controls. Data are mean \pm SD of three independent experiments, $*(P<0.05)$ indicate statistically significant differences between ck and compounds 1-10. 


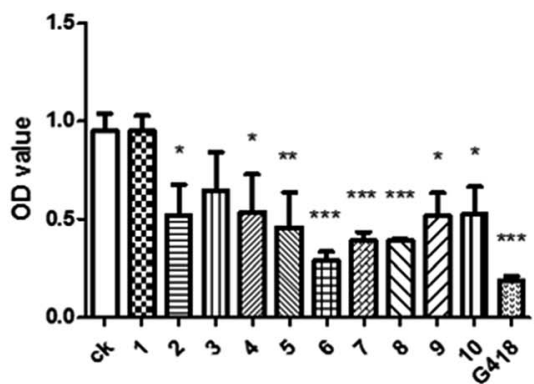

$\mathbf{E}$

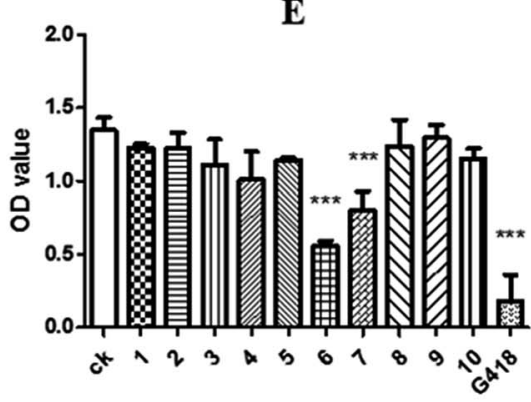

G

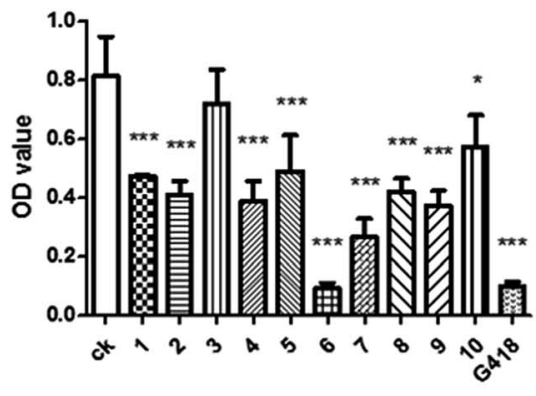

$\mathbf{F}$

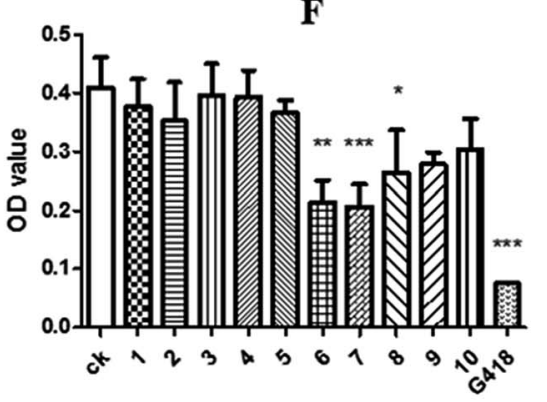

$\mathbf{H}$

Fig. 7 Antifungal activities of compounds 1-10 against C. albicans (E) Cylindrocarpon didynum, (F), Alternaria panax (G), Fusarium solani (H); G418 was used as positive control. Data are mean \pm SD of three independent experiments, $*(P<0.05)$ indicate statistically significant differences between ck and compounds 1-10.

appropriate chain length. During this period, the conversion of acetyl-CoA into malonyl-CoA increased the acidity of the $\alpha$ hydrogens, and thus provided a better nucleophile for the Claisen condensation. Further cyclization and other modifications can create a wide range of BFA series compounds. The stereochemistry in the chain is controlled by the condensation and reduction steps during chain extension, such as compounds 1-5. And a reassuring feature is that there appears to be a considerable degree of stereochemical uniformity throughout the known macrolide antibiotics 6 and 7.44

\section{Conclusions}

In conclusion, the endophyte metabolites study described the isolation and structural identification of five new BFA analogues, along with five known compounds from Penicillium sp. Their cytotoxic activities were evaluated against four kinds of human cancer cell lines. Compounds 6-7 had higher cytotoxicity towards a panel of cancer cells. Among them, compounds 6-7 exhibited higher cytotoxic activities than the positive control LODDC for HepG2 and Huh7 cells. By means of cell cycle detection using flow cytometry, we discovered that compounds 6-7 inhibited HepG2 cell proliferation by arresting at the $\mathrm{S}$ phase. The antimicrobial results showed that compound 1, 4-7, 9-10 had a satisfactory antibacterial activity at least on one of the pathogens tested. Compoud 1-2 and 4-10 had the ability to inhibit the growth of Cylindrocarpon didynum. Besides, the structure-activity relationships were discussed based on cytotoxicity and antimicrobial results, and the plausible biosynthetic pathways of compounds 1-7 were also proposed. The investigation indicated that endophytic fungi
Penicillium sp. SYP-ZL1031 produced potential candidate of bioactive metabolites for antitumor, antiviral, antibacterial and have the potential as biological control agents of root-rot disease of $P$. notoginseng.

\section{Experimental section}

\section{General experimental procedures}

Optical rotations were measured with a P-2000 Digital Polarimeter (JASCO, United Kingdom). UV spectra were recorded on an Inesa L5S spectrophotometer. IR spectra were obtained with an Equinox55 spectrophotometer in $\mathrm{KBr}$ discs. Circular dichroism (CD) spectrum was recorded on a MOS-450 spectrometer (BioLogic Science, France). The NMR spectra were run on Bruker AVANCE-125 or AVANCE-600 NMR spectrometers (Rheinstetten, Germany). HR-ESI-MS data were obtained on a Bruker Customer micr OTOF-Q 125 mass spectrometer (MA, Germany).

\section{Isolation and identification of fungal material}

The three-year-old healthy $P$. notoginseng was collected from Wenshan, Yunnan province of China. After surface sterilization with $75 \% \mathrm{EtOH}$ for $60 \mathrm{~s}$, the root of $P$. notoginseng was rinsed in sterile water. Then the root was aseptically cut into small pieces and pressed onto potato dextrose agar plates. The DNA sequence of the 18S-ITS1-5.8S-ITS2-28S, which derived from the fungal strain has been submitted and deposited at GenBank with accession number KU360251. BLAST search result revealed that the isolate belongs to the genus Penicillium, and showed high identity $(100 \%)$ to the species of Penicillium sp., so we named it Penicillium sp. SYP-ZL1031. 


\section{Fermentation and extraction}

Fermentation was carried out in 50 Erlenmeyer flasks $(250 \mathrm{~mL})$ each containing $75 \mathrm{~g}$ rice. Sterile water $(100 \mathrm{~mL})$ was added to each flask, and the contents were autoclaved at $121{ }^{\circ} \mathrm{C}$ for $30 \mathrm{~min}$. After cooling to room temperature, each flask was inoculated with $2.0 \mathrm{~mL}$ of the spore and incubated at $28{ }^{\circ} \mathrm{C}$ for 30 days. The fermented material was extracted thoroughly with ethyl acetate $(20 \mathrm{~L})$ and all the organic solvent was concentrated under reduced pressure to afford the crude extract $(75 \mathrm{~g})$, which was dissolve again using $90 \% \mathrm{MeOH}-\mathrm{H}_{2} \mathrm{O}$. Then, it was extracted by the same volume hexane to obtain the whole crude extract $(50 \mathrm{~g})$.

\section{Purification}

The extract chromatographed over silica gel column chromatography (CC) $(25 \times 10 \mathrm{~cm})$ using $\mathrm{CH}_{2} \mathrm{Cl}_{2}-\mathrm{MeOH}$ gradient elution $(100: 1$ to $1: 1)$ to give four fractions (A-D). The fraction B (27.5 g) eluted with $\mathrm{MeOH}-\mathrm{H}_{2} \mathrm{O}(1: 9$ to $10: 0)$ was further separated by ODS column to obtain fifteen subfractions (B1B15). Fractions B4-B12 showed antimicrobial activity by $96-w e l l$ flat-bottomed plate assay.

Then the subfraction B4 was purified by Sephadex LH-20, giving five subfractions (fraction B4-1 to fraction B4-5). Fraction B4-2 was further purified by semi-preparative HPLC $\left(\mathrm{CH}_{3} \mathrm{CN}-\mathrm{H}_{2} \mathrm{O}, \mathrm{v} / \mathrm{v} 25: 75,3.0 \mathrm{~mL} \mathrm{~min}^{-1}\right)$ to yield compound 1 (9.8 mg). Compounds 2 (9.3 mg) and $3(10.4 \mathrm{mg})$ were obtained from B4-4 and B4-5 separately by semi-preparative HPLC

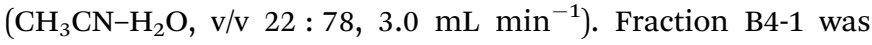
applied on semi-preparative $\mathrm{HPLC}\left(\mathrm{CH}_{3} \mathrm{CN}-\mathrm{H}_{2} \mathrm{O}\right.$, v/v $20: 80,3.0$ $\left.\mathrm{mL} \mathrm{min}^{-1}\right)$ to afford the compound $4(9.2 \mathrm{mg})$ and $5(14.8 \mathrm{mg})$. A colorless needle crystal was crystallization precipitation in $\mathrm{MeOH}$ of subfraction B7, which was compound 6 (38.9 mg). Subfraction B12 was further passed over a Sephadex LH-20 column and then purified by semipreparative HPLC $\left(\mathrm{CH}_{3} \mathrm{CN}-\right.$ $\mathrm{H}_{2} \mathrm{O}, \mathrm{v} / \mathrm{v} 35: 65,3.0 \mathrm{~mL} \mathrm{~min}^{-1}$ ) to produce compound 7 (9.7 mg) and compound $10(10.3 \mathrm{mg})$. Subfraction B10 was further purified by semi-preparative HPLC $\left(\mathrm{CH}_{3} \mathrm{CN}-\mathrm{H}_{2} \mathrm{O}\right.$, v/v 30 : 70, 3.0 $\left.\mathrm{mL} \mathrm{min}^{-1}\right)$ to yield compound $8(9.0 \mathrm{mg})$ and $9(8.1 \mathrm{mg})$.

Brefeldin E1 (1). Colorless oil; $[\alpha]_{\mathrm{D}}^{20}-72.50(c 0.5, \mathrm{MeOH})$; CD $(\mathrm{MeOH}) \mathrm{nm}(\Delta \varepsilon) 208$ (4.64), 294 (-2.03); UV (MeOH) $\lambda_{\max }(\log \varepsilon)$ $203 \mathrm{~nm}$; IR (KBr) $\nu_{\max } 3420,2923,2856,1737,1657,1566,1385$, 1245, 1156, 1109, 1052, 1032, 1018, $606 \mathrm{~cm}^{-1} ;{ }^{1} \mathrm{H}$ and ${ }^{13} \mathrm{C}-\mathrm{NMR}$ data, see Table 1; HR-ESI-MS $m / z 333.1312[\mathrm{M}+\mathrm{Na}]^{+}$(calcd for $\mathrm{C}_{16} \mathrm{H}_{22} \mathrm{NaO}_{6}$ ).

Brefeldin E2 (2). Colorless oil; $[\alpha]_{\mathrm{D}}^{20}-12.50(c$ 0.5, MeOH); CD $(\mathrm{MeOH}) \mathrm{nm}(\Delta \varepsilon) 195$ (-3.32), 208 (5.57); UV (MeOH) $\lambda_{\max }(\log \varepsilon)$ $203 \mathrm{~nm}$; IR (KBr) $\nu_{\max } 3423,2924,1711,1656,1381,1248,1113$, 1051, 1031, $603 \mathrm{~cm}^{-1} ;{ }^{1} \mathrm{H}$ and ${ }^{13} \mathrm{C}-\mathrm{NMR}$ data, see Table 1 ; HRESI-MS $m / z 361.1623[\mathrm{M}+\mathrm{Na}]^{+}$(calcd for $\mathrm{C}_{18} \mathrm{H}_{26} \mathrm{NaO}_{6}$ ).

Brefeldin E3 (3). Colorless oil; $[\alpha]_{\mathrm{D}}^{20}-27.70(c 0.5, \mathrm{MeOH}) ; \mathrm{CD}$ $(\mathrm{MeOH}) \mathrm{nm}(\Delta \varepsilon) 197$ (0.50), 223 (1.05); UV (MeOH) $\lambda_{\max }(\log \varepsilon)$ $203 \mathrm{~nm}$; IR (KBr) $\nu_{\max } 3442,2169,1711,1632,1402,1384,1267$, 1117, 1015, 823, $703 \mathrm{~cm}^{-1} ;{ }^{1} \mathrm{H}$ and ${ }^{13} \mathrm{C}-\mathrm{NMR}$ data, see Table 1; HR-ESI-MS $m / z 361.1616[\mathrm{M}+\mathrm{Na}]^{+}$(calcd for $\mathrm{C}_{18} \mathrm{H}_{26} \mathrm{NaO}_{6}$ ).

Brefeldin E4 (4). Colorless oil; $[\alpha]_{\mathrm{D}}^{20}-106.00(c$ 0.5, MeOH); $\mathrm{CD}(\mathrm{MeOH}) \mathrm{nm}(\Delta \varepsilon) 210$ (3.74); UV (MeOH) $\lambda_{\max }(\log \varepsilon) 200 \mathrm{~nm}$;
IR (KBr) $\nu_{\max } 3391,2931,2857,1732,1712,1658,1556,1418$, 1379, 1251, 1125, 1082, 1025, 981, 883, $\mathrm{cm}^{-1} ;{ }^{1} \mathrm{H}$ and ${ }^{13} \mathrm{C}-\mathrm{NMR}$ data, see Table 1 ; HR-ESI-MS $m / z 363.1787[\mathrm{M}+\mathrm{Na}]^{+}$(calcd for $\mathrm{C}_{18} \mathrm{H}_{28} \mathrm{NaO}_{6}$ ).

Brefeldin E5 (5). Colorless oil; $[\alpha]_{\mathrm{D}}^{20}-192.00(c$ 0.5, MeOH); $\mathrm{CD}(\mathrm{MeOH}) \mathrm{nm}(\Delta \varepsilon) 194$ (-1.59), 207 (4.76); UV (MeOH) $\lambda_{\max }$ $(\log \varepsilon) 200 \mathrm{~nm}$; IR (KBr) $\nu_{\max } 3398,2929,2857,1736,1659,1563$, 1406, 1247, 1125, 1083, 1023, 979, 885, 803, 725, $610 \mathrm{~cm}^{-1} ;{ }^{1} \mathrm{H}$ and ${ }^{13} \mathrm{C}-\mathrm{NMR}$ data, see Table 1 ; HR-ESI-MS $m / z 363.1783[\mathrm{M}+$ $\mathrm{Na}]^{+}$(calcd for $\mathrm{C}_{18} \mathrm{H}_{28} \mathrm{NaO}_{6}$ ).

Brefeldin A (6). Colorless needle crystals, HR-ESI-MS $\mathrm{m} / \mathrm{z}$ $303.2144[\mathrm{M}+\mathrm{Na}]^{+}$(calcd for $\left.\mathrm{C}_{16} \mathrm{H}_{24} \mathrm{NaO}_{4}\right){ }^{1} \mathrm{H}-\mathrm{NMR}(400 \mathrm{MHz}$, DMSO) $\delta: ~ 7.31-7.36(\mathrm{dd}, J=15.6,2.4 \mathrm{~Hz}, 1 \mathrm{H}), 5.72-5.67(\mathrm{dd}, J=$ 15.6, $2.4 \mathrm{~Hz}, 1 \mathrm{H}), 5.70-5.62(\mathrm{~m}, 1 \mathrm{H}), 5.22-5.16(\mathrm{~m}, 1 \mathrm{H}), 4.70(\mathrm{~m}$, $1 \mathrm{H}), 4.03(\mathrm{~m}, 1 \mathrm{H}), 3.92(\mathrm{~m}, 1 \mathrm{H}), 2.31(\mathrm{~m}, 1 \mathrm{H}), 1.95-2.30(\mathrm{~m}, 2 \mathrm{H})$, 1.61-1.83 (m, 6H), $1.48(\mathrm{~m}, 1 \mathrm{H}), 1.29(\mathrm{~m}, 1 \mathrm{H}), 1.17(\mathrm{~d}, J=6.4 \mathrm{~Hz}$, $3 \mathrm{H}), 0.73(\mathrm{~m}, 1 \mathrm{H}) ;{ }^{13} \mathrm{C}-\mathrm{NMR}$ (125 MHz, DMSO) $\delta: 165.8,154.5$, 137.1, 129.4, 116.3, 74.3, 70.9, 70.5, 51.8, 43.3, 43.0, 40.9, 33.4, 31.4, 26.5, 20.8.

Brefeldin A 7-O-acetate (7). Colorless needle crystals, HR-ESIMS $m / z 345.1677[\mathrm{M}+\mathrm{Na}]^{+}$(calcd for $\mathrm{C}_{18} \mathrm{H}_{26} \mathrm{NaO}_{5}$ ). ${ }^{1} \mathrm{H}-\mathrm{NMR}$ (400 MHz, DMSO) $\delta: 7.33(\mathrm{dd}, J=15.5,2.9 \mathrm{~Hz}, 1 \mathrm{H}), 5.73-5.69(\mathrm{dd}, J=$ $15.5,2.0 \mathrm{~Hz}, 1 \mathrm{H}), 5.72(\mathrm{~m}, 1 \mathrm{H})$ 5.20-5.14 (m, 1H), 5.00-4.95 (m, $1 \mathrm{H}), 4.74-4.67$ (m, 1H), $3.99(\mathrm{~m}, 1 \mathrm{H}), 2.44(\mathrm{~m}, 1 \mathrm{H}), 2.17(\mathrm{~m}, 1 \mathrm{H})$, $1.99(\mathrm{~m}, 1 \mathrm{H}), 1.97(\mathrm{~s}, 3 \mathrm{H}), 1.94(\mathrm{~m}, 1 \mathrm{H}), 1.83-1.67(\mathrm{~m}, 5 \mathrm{H}), 1.52-$ $1.40(\mathrm{~m}, 2 \mathrm{H}), 1.17$ (d, $J=6.28 \mathrm{~Hz} 3 \mathrm{H}), 0.74(\mathrm{~m}, 1 \mathrm{H}) ;{ }^{13} \mathrm{C}-\mathrm{NMR}$ (125 MHz, DMSO) $\delta: 170.1,165.6,154.1,136.3,130.2,116.5$, 74.9, 73.8, 70.8, 51.7, 42.7, 39.6, 38.1, 33.5, 31.4, 26.4, 21.0, 20.7.

Alternariol-5-O-methyl ether (8). Yellow powder, HR-ESI-MS $m / z 295.1338[\mathrm{M}+\mathrm{Na}]^{+}$(calcd for $\mathrm{C}_{15} \mathrm{H}_{12} \mathrm{NaO}_{5}$ ). ${ }^{1} \mathrm{H}-\mathrm{NMR}(400$ MHz, DMSO) $\delta: 11.91$ (s, 1H), 10.40 (brs, 1H), 7.24 (d, $J=2.3 \mathrm{~Hz}$, $1 \mathrm{H}), 6.72(\mathrm{~d}, J=2.3 \mathrm{~Hz}, 1 \mathrm{H}), 6.65(\mathrm{~d}, J=2.3 \mathrm{~Hz}, 1 \mathrm{H}), 6.62(\mathrm{~d}, J=$ $2.3 \mathrm{~Hz}, 1 \mathrm{H}), 3.91$ (s, 3H), 2.66 (s, 3H). ${ }^{13} \mathrm{C}-\mathrm{NMR}(125 \mathrm{MHz}$, DMSO) $\delta: 166.1,164.6,164.1,157.0,151.5,138.4$, 137.2, 116.4, 106.9, 102.1, 101.4, 99.2, 98.3, 55.8, 24.5.

3'-Hydroxyalternariol-5-O-methyl ether (9). Yellow powder, HR-ESI-MS $m / z 301.1431\left[\mathrm{M}+\mathrm{Na}^{+}\right.$(calcd for $\mathrm{C}_{15} \mathrm{H}_{12} \mathrm{NaO}_{6}$ ). ${ }^{1} \mathrm{H}-$ NMR (400 MHz, DMSO) $\delta: 11.89$ (s, 1H), 9.90 (s, 1H), 9.10 (s, 1H), 7.21 (brs, 1H), $6.72(\mathrm{~s}, 1 \mathrm{H}), 6.60$ (brs, 1H), 3.90 (s, 3H), $2.72(\mathrm{~s}$,

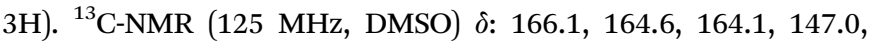
141.5, 138.4, 131.2, 126.4, 116.9, 109.1, 103.4, 99.2, 98.3, 55.8, 24.5.

Mangrovamides A (10). White powder, HR-ESI-MS $\mathrm{m} / \mathrm{z}$ $478.2883[\mathrm{M}+\mathrm{Na}]^{+}$(calcd for $\left.\mathrm{C}_{28} \mathrm{H}_{36} \mathrm{~N}_{3} \mathrm{O}_{4}\right) .{ }^{1} \mathrm{H}-\mathrm{NMR}(400 \mathrm{MHz}$, DMSO) 7.55 (d, $J=8.4 \mathrm{~Hz} \mathrm{1H}), 6.52$ (d, $J=8.4 \mathrm{~Hz} 1 \mathrm{H}), 3.55$ (d, $J$ $=10.8 \mathrm{~Hz} 1 \mathrm{H}), 3.05(\mathrm{~m}, 1 \mathrm{H}), 3.03(\mathrm{~m}, 1 \mathrm{H}), 2.86(\mathrm{~s}, 3 \mathrm{H}), 2.74(\mathrm{~d}, J$ $=16.2 \mathrm{~Hz} 2 \mathrm{H}), 2.67(\mathrm{~m}, 1 \mathrm{H}), 2.52(\mathrm{~d}, J=10.8 \mathrm{~Hz} 1 \mathrm{H}), 2.40(\mathrm{~m}$, $1 \mathrm{H}), 2.30(\mathrm{dd}, J=10.8,4.2 \mathrm{~Hz} 1 \mathrm{H}), 1.90(\mathrm{~m}, 1 \mathrm{H}), 1.89(\mathrm{~m}, 1 \mathrm{H})$, $1.88(\mathrm{~m}, 1 \mathrm{H}), 1.77(\mathrm{~m}, 1 \mathrm{H}), 1.62(\mathrm{~m}, 1 \mathrm{H}), 1.41(\mathrm{~s} 3 \mathrm{H}), 1.37(\mathrm{~s}, 3 \mathrm{H})$, 1.04 (d, $J=6.8 \mathrm{~Hz} 3 \mathrm{H}), 1.00$ (s, 3H), 0.68 (s, 3H) ${ }^{13} \mathrm{C}-\mathrm{NMR}(125$ MHz, DMSO) $\delta: 192.7,183.4,171.5,158.6,142.5,132.8,121.5$, 108.9, 104.8, 79.2, 66.9, 64.6, 60.2, 59.0, 52.5, 51.8, 48.0, 45.7, $39.7,36.0,30.0,26.9,26.5,25.8,25.2,23.4,20.0,13.1$.

\section{Cytotoxic activity screening ${ }^{45,46}$}

Human renal epithelial cell (293), hepatocellular carcinoma cell (HepG2, Huh7) and oral epidermoid carcinoma cell (KB) were 
obtained from the American Type Culture Collection (USA). Cytotoxicity of 1-10 were evaluated against 293 (human renal epithelial cell line) cells. Incubated cells at 2500 cells per well onto 96 wells overnight. Added drugs and incubated for three days. Added $10 \mu \mathrm{L}$ dye and incubated for one hour at $37^{\circ} \mathrm{C}$. Read results at $450 \mathrm{~nm}$ on microplate reader (Thermo Scientific, USA). And HepG2, Huh7 (human hepatocellular carcinoma cell), KB (human oral epidermoid carcinoma cell) were also screened as follow. Seeded cells at 5000 cells per well onto 48 wells and incubated overnight. Added drugs and incubated for 3 doubling times. Removed media and added $0.5 \%$ methylene blue in $50 \%$ ethanol. Incubated plates at room temp for one hour. Washed plates gently with water and air dried for overnight. Added $0.2 \mathrm{~mL} 1 \%$ sarkosyl and rotated at room temp for 3 hours. Read results at $595 \mathrm{~nm}$ on microplate reader (Thermo Scientific, USA).

\section{HCV screening ${ }^{47}$}

The HCV genotype 1b (Con1 isolate) subgenomic replicon cell line with a luciferase reporter (Huh-luc/neo-ET) was kindly provided by Ralf Bartenschlager from the University of Heidelberg. ${ }^{48}$ Seeded cells at 20000 cells per well onto 48 wells. Incubated them overnight then added drugs. Incubated 3 days, then removed media and washed with PBS. Added $50 \mu \mathrm{L}$ lysis buffer and rotated $15 \mathrm{~min}$ at room temp. Frozen cells then thawed and transfered the lysate to a white plate. Added $50 \mu \mathrm{L}$ luciferase buffer and read results on Farcyte luminometer (Thermo Scientific, USA).

\section{HBV screening ${ }^{49}$}

HBV intracellular replicative intermediates were isolated from transfected cells as described by Zhong et al. ${ }^{\mathbf{5 0}}$ Southern Blot method was used to analyze HBV. DNA isolated from 2.2.15 (HepG2 transfected with HBV) cells after being treated with drugs for 9 days and incubated a total of 12 days. Interferon was used as the positive control.

\section{Cell cycle assay ${ }^{51}$}

The cell cycle analyzed by flow cytometry. Upon CPT treatment at $1000 \mathrm{nM}$ for $24 \mathrm{~h}, \mathrm{HepG} 2$ cells with or without added compounds 6-7 (0.072 $\mu \mathrm{M}$ and $0.1 \mu \mathrm{M})$ were harvested, centrifuged at $300 \times g$ for $5 \mathrm{~min}$, washed twice with PBS, and fixed in $100 \%$ methanol on ice for at least $1 \mathrm{~h}$. The cells were then washed once with PBS and resuspended in $1 \mathrm{~mL}$ PBS containing $250 \mu \mathrm{g} \mathrm{mL}{ }^{-1}$ RNase A (type I-A; Sigma-Aldrich) and propidium iodide $\left(50 \mu \mathrm{g} \mathrm{mL} \mathrm{mL}^{-1}\right)$. Flow cytometry was carried out on BD FACSCalibur and data was analyzed using Flow Jo software.

\section{Antimicrobial activity screening ${ }^{52}$}

Escherichia coli ATCC25922, Staphylococcus aureus ATCC6538, Bacillus cereus ATCC14579, Candida albicans ATCC 10231, Klebsiella pneumoniae ATCC 11296 were cultivated at $37{ }^{\circ} \mathrm{C}$ for $24 \mathrm{~h}$ in LB media using glass tubes. Cylindrocarpon didynum, Alternaria panax, Fusarium solani were cultivated at $28{ }^{\circ} \mathrm{C}$ for 7 days in PDA media using culture dishes. The LB/PDB bacterial/ spore suspension was diluted to the predetermined starting concentration (optical density at $600 \mathrm{~nm} ; \mathrm{OD}_{600}=0.2$ ), and 1 $\mathrm{mL}$ of bacterial/spore solution was added into $24 \mathrm{~mL}$ media. The bacterial/spore solution was transferred into a 96-well plate (198 $\mu \mathrm{L}$ per well) and the $2 \mu \mathrm{L}$ of compounds $\mathbf{1 - 1 0}\left(20 \mathrm{~g} \mathrm{~L}^{-1}\right)$ reached the final reaction volume of $200 \mu \mathrm{L}$ per well. Here, untreated bacterial solution served as the negative control group, and bacterial solutions treated with ampicillin $(0.02 \mathrm{~g}$ $\left.\mathrm{L}^{-1}\right)$, kanamycin (0.02 $\left.\mathrm{g} \mathrm{L}^{-1}\right)$, geneticin (G418) $\left(0.02 \mathrm{~g} \mathrm{~L}^{-1}\right)$ served as positive control groups, respectively. The growth was measured after 24 hours of incubation at $37 / 28{ }^{\circ} \mathrm{C}$ using a multiplate photometric reader. Every experiment was performed in three biological replicates in triplicate to validate the screening method.

\section{Statistical analysis}

The statistical analysis was performed using OriginPro 9.0.0 software. All the data were present as means \pm SD for triplicate experiments. One-way analysis of variance (ANOVA) followed by Turkey's test was used to express the statistical differences between groups. The value of $P<0.05$ was considered statistically significant.

\section{Conflict of interest}

There are no conflicts of interest to declare.

\section{Acknowledgements}

The authors thank the Institute of Nuclear Magnetic and Mass Spectrometry Testing Center, Shenyang Pharmaceutical University. This work is supported by grants from the Key Project of Yunnan Provincial Natural Science Foundation (2016ZF001-001, 2017IB038), Yung-Chi Cheng academician workstation of Yunnan provincial academy of science and technology (2015IC017) and National Science and Technology Major Project (2017ZX09305001-002).

\section{References}

1 T. T. X. Dong, X. M. Cui, Z. H. Song, K. J. Zhao, Z. N. Ji, C. K. Lo and K. W. K. Tsim, J. Agric. Food Chem., 2013, 51, 4617-4623.

2 N. Zhou, Y. Tang, R. F. Keep, X. Ma and J. Xiang, Phytomedicine, 2014, 21, 1189-1195.

3 R. Uzayisenga, P. A. Ayeka and Y. Wang, Phytother. Res., 2014, 28, 510-516.

4 P. Wang, J. Cui, X. Du, Q. Yang, C. Jia, M. Xiong, X. Yu, L. Li, W. Wang, Y. Chen and T. Zhang, J. Ethnopharmacol., 2014, 154, 663-671.

5 H. B. Guo, X. M. Cui, N. An and G. P. Cai, Genet. Resour. Crop Evol., 2010, 57, 453-460.

6 S. G. Lee, Res. Plant Dis., 2004, 10, 248-259.

7 J. H. Lee, Y. H. Yu, Y. H. Kim, S. H. Ohh and W. M. Park, Plant Pathol. J., 1990, 6, 13-20. 
8 L. Ma, Y. H. Cao, M. H. Cheng, Y. Huang, M. H. Mo, Y. Wang, J. Z. Yang and F. X. Yang, Antonie van Leeuwenhoek, 2013, 103, 299-312.

9 Z. Y. Fan, C. P. Miao, X. G. Qiao, Y. K. Zheng, H. H.Chen, Y. W. Chen, L. H. Xu, L. X. Zhao and H. L. Guan, J. Ginseng Res., 2016, 40, 97-104.

10 Y. K. Zheng, C. P. Miao, H. H. Chen, F. F. Huang, Y. M. Xia, Y. W. Chen and L. X. Zhao, J. Ginseng Res., 2016, 40, 1-8.

11 J. L. Chen, S. Z. Sun, C. P. Miao, K. Wu, Y. W. Chen, L. H. Xu, H. L. Guan and L. X. Zhao, J. Ginseng Res., 2016, 40, 315-324.

12 S. K. Deshmukh, S. A. Verekar and S. V. Bhave, Front. Microbiol., 2014, 5, 715-725.

13 G. Strobel, Science, 1993, 260, 214-216.

14 L. Liang, H. E. Jun and Y. U. X. Ping, Acta Agric. BorealiOccident. Sin., 2006, 15, 85-89.

15 S. C. Puri, V. Verma, T. Amna, G. N. Qazi and M. Spiteller, J. Nat. Prod., 2005, 68, 1717-1719.

16 S. Sirikantaramas, T. Asano, H. Sudo, M. Yamazaki and K. Saito, Curr. Pharm. Biotechnol., 2007, 8, 196-202.

17 A. L. Leitãoa and F. J. Enguita, Microbiol. Res., 2016, 183, 818.

18 M. Marinho, A. M. D. R. Rodrigues-Filho, E. Moitinho, M. D. L. R. Santos and S. Lourivaldo, J. Braz. Chem. Soc., 2005, 16, 280-283.

19 A. Svendsen and J. C. Firsvad, Mycol. Res., 1994, 98, 13171328.

20 R. Nicoletti, M. L. Ciavatta, E. Buommino and M. A. Tufano, Int. J. Biomed. Pharmaceut. Sci., 2008, 2, 1-23.

21 M. Zhu, X. Zhang, H. Feng, J. Dai, J. Li, Q. Che, Q. Gu, T. Zhu and D. Li, J. Nat. Prod., 2017, 80, 71-75.

22 V. L. Singleton, N. Bohonos and A. J. Ullstrup, Nature, 1958, 181, 1072-1073.

23 V. Betina, J. Fuska, A. Kjaer, P. Nemec and R. H. Shapiro, J. Antibiot., 1966, 19, 115-117.

24 V. Betina, P. Nemec, J. Dobias and Z. Barath, Folia Microbiol., 1962, 7, 353-357.

25 Y. J. Wang, Y. F. Wu, F. Xue, Z. X. Wu, Y. P. Xue, Y. G. Zheng and Y. C. Shen, J. Chromatogr. B: Anal. Technol. Biomed. Life Sci., 2012, 895, 146-153.

26 J. W. Zhu, H. Nagasawa, F. Nagura, S. B. Mohamad, Y. Uto, K. Ohkura and H. Hori, Bioorg. Med. Chem., 2000, 8, 455-463.

27 Z. Kossaczka, J. Drgonova, B. Podobova, V. Betina and V. Farkas, Can. J. Microbiol., 1995, 41, 971-977.

28 B. S. Jeunemaitre and C. Hawes, Biol. Cell., 1992, 74, 325328.

29 D. E. Larsson, H. Lövborg, L. Rickardson, R. Larsson, K. Oberg and D. Granberg, Anticancer Res., 2006, 26, 41254129.

30 W. Eric, R. G. Sellers and D. M. Peehl, J. Urol., 2000, 164, 836841.

31 N. H. Meyer and K. Zangger, ChemPhysChem, 2014, 15, 4955.

32 A. Lupulescu, G. L. Olsen and L. Frydman, J. Magn. Reson., 2012, 218, 141-146.
33 H. Furukawa, T. Hamada, M. K. Hayashi, T. Haga, Y. Muto, H. Hirota, S. Yokoyama, K. Nagasawa and M. Ishiguro, Mol. Pharmacol., 2002, 62, 778-787.

34 T. Kimura, N. Matubayasi and M. Nakahara, Biophys. J., 2004, 86, 1124-1137.

35 B. Yu, N. Zhu and Z. Du, Helv. Chim. Acta, 2010, 93, 324-328.

36 Y. N. An, X. Zhang, T. Y. Zhang, M. Y. Zhang, Q. Zhang,

X. Y. Deng, F. Zhao, L. J. Zhu, G. Wang, J. Zhang, Y. X. Zhang, B. Liu and X. S. Yao, Sci. Rep., 2016, 6, 2739627410.

37 E. M. K. Wijeratne, B. P. Bashyal, M. X. Liu, D. D. Rocha, G. M. K. B. Gunaherath, J. M. U'Ren, M. K. Gunatilaka, A. E. Arnold, L. Whitesell and A. A. L. Gunatilaka, J. Nat. Prod., 2012, 75, 361-369.

38 F. W. Wang, R. H. Jiao, A. B. Cheng, S. H. Tan and Y. C. Song, World J. Microbiol. Biotechnol., 2007, 23, 79-83.

39 M. Shibazaki, H. Yamaguchi, T. Sugawara, K. Suzuki and T. Yamamoto, J. Biosci. Bioeng., 2003, 96, 344-348.

40 J. Sun, T. Awakawa, H. Noguchi and I. Abe, Bioorg. Med. Chem. Lett., 2012, 22, 6397-6400.

41 B. Yang, J. Dong, X. Lin, X. Zhou, Y. Zhang and Y. Liu, Tetrahedron, 2014, 70, 3859-3863.

42 M. A. Fernandez-Herrera, S. Mohan, H. Lopez-Munoz, J. M. V. Hernandez-Vazquez, E. Perez-Cervantes, M. L. Escobar-Sanchez, L. Sanchez-Sanchez, I. Regla, B. M. Pinto and J. Sandoval-Ramirez, Eur. J. Med. Chem., 2010, 45, 4827-4837.

43 M. Liu, G. Luo, Y. Wang, R. Xu, Y. Wang, W. He, J. Tan, M. Xing and J. Wu, Sci. Rep., 2017, 7, 436-450.

44 P. M. Dewick, Medicinal Natural Products: A Biosynthetic Approach, John Wiley Sons Ltd., England, 2nd edn, 2002, pp. 35-96.

45 K. L. Grove, X. Guo, S. H. Liu, Z. Gao and C. K. Chu, Cancer Res., 1995, 55, 3008-3011.

46 S. Anguille, E. Lion, J. Tel, I. J. Vries, K. Couderé, P. D. Fromm, V. F. V. Tendeloo, E. L. Smits and Z. N. Berneman, PLoS One, 2012, 7, 51138-51151.

47 Y. Cheng, L. K. Tsou, J. Cai, T. Aya, G. E. Dutschman, E. A. Gullen, S. P. Grill, A. P. C. Chen, B. D. Lindenbach, A. D. Hamilton and Y. C. Cheng, Antimicrob. Agents Chemother., 2010, 54, 197-206.

48 J. M. Vrolijk, A. Kaul, B. E. Hansen, V. Lohmann, B. L. Haagmans, S. W. Schalma and R. Bartenschlager, $J$. Virol. Methods, 2003, 110, 201-209.

49 S. L. Doong, C. H. Tsai, R. F. Schinazi, D. C. Liotta and Y. C. Cheng, Proc. Natl. Acad. Sci. U. S. A., 1991, 88, 84958499.

50 Y. Zhong, J. Lv, J. Li, X. Xing, H. Zhu, H. Su, L. Chen and X. Zhou, Antiviral Res., 2012, 93, 185-190.

51 C. J. Wang, W. Lam, S. Bussom, H. M. Chang and Y. C. Cheng, DNA Repair, 2009, 8, 1179-1189.

52 C. Zutz, D. Bandian, B. Neumayer, F. Speringer, M. Gorfer, M. Wagner, J. Strauss and K. Rychli, BioMed Res. Int., 2014, 10, 540292-540305. 